\title{
Correction to: miR-205-5p inhibits human endometriosis progression by targeting ANGPT2 in endometrial stromal cells
}

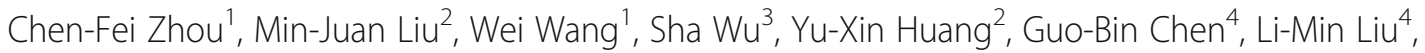
Dong-Xian Peng ${ }^{2}$, Xue-Feng Wang ${ }^{2}$, Xu-Zi Cai ${ }^{2}$, Xiao-Xuan Li ${ }^{2}$, Wan-Qin Feng ${ }^{2}$ and Ying $\mathrm{Ma}^{2^{*}}$

\section{Correction to: Stem Cell Res Ther (2019) 10:287 \\ https://doi.org/10.1186/s13287-019-1388-5}

The original article [1] contains an error in Fig. 1 whereby in sub-panel A of Fig. 1, the blue and red thresholds were mistakenly reversed. The correct version of subpanel A in Fig. 1 can be viewed ahead.

\footnotetext{
Author details

'Department of Obstetrics and Gynecology, The First Affiliated Hospital of Guangzhou Medical University, Guangzhou 510120, China. ${ }^{2}$ Department of Obstetrics and Gynecology, Zhujiang Hospital of Southern Medical University, No.253, Middle Gongyeda Road, Haizhu District, Guangzhou 510280, China. ${ }^{3}$ Department of Immunology/Guangdong Provincial Key Laboratory of Proteomics, School of Basic Medical Sciences, Southern Medical University, Guangzhou 510515, China. ${ }^{4}$ Department of Obstetrics and Gynecology, Shenzhen Maternal and Child Healthcare Hospital of Southern Medical University, Shenzhen 518028, China.
}

Published online: 20 May 2020

\section{Reference}

1. Zhou C-F, et al. miR-205-5p inhibits human endometriosis progression by targeting ANGPT2 in endometrial stromal cells. Stem Cell Res Ther. 2019;10: 287 https://doi.org/10.1186/s13287-019-1388-5

\footnotetext{
The original article can be found online at https://doi.org/10.1186/s13287019-1388-5.

* Correspondence: mayingwuzhuoyi@126.com

${ }^{2}$ Department of Obstetrics and Gynecology, Zhujiang Hospital of Southern

Medical University, No.253, Middle Gongyeda Road, Haizhu District, Guangzhou 510280, China

Full list of author information is available at the end of the article
}

C C The Author(s). 2020 Open Access This article is licensed under a Creative Commons Attribution 4.0 International License, which permits use, sharing, adaptation, distribution and reproduction in any medium or format, as long as you give appropriate credit to the original author(s) and the source, provide a link to the Creative Commons licence, and indicate if changes were made. The images or other third party material in this article are included in the article's Creative Commons licence, unless indicated otherwise in a credit line to the material. If material is not included in the article's Creative Commons licence and your intended use is not permitted by statutory regulation or exceeds the permitted use, you will need to obtain permission directly from the copyright holder. To view a copy of this licence, visit http://creativecommons.org/licenses/by/4.0/ The Creative Commons Public Domain Dedication waiver (http://creativecommons.org/publicdomain/zero/1.0/) applies to the data made available in this article, unless otherwise stated in a credit line to the data. 


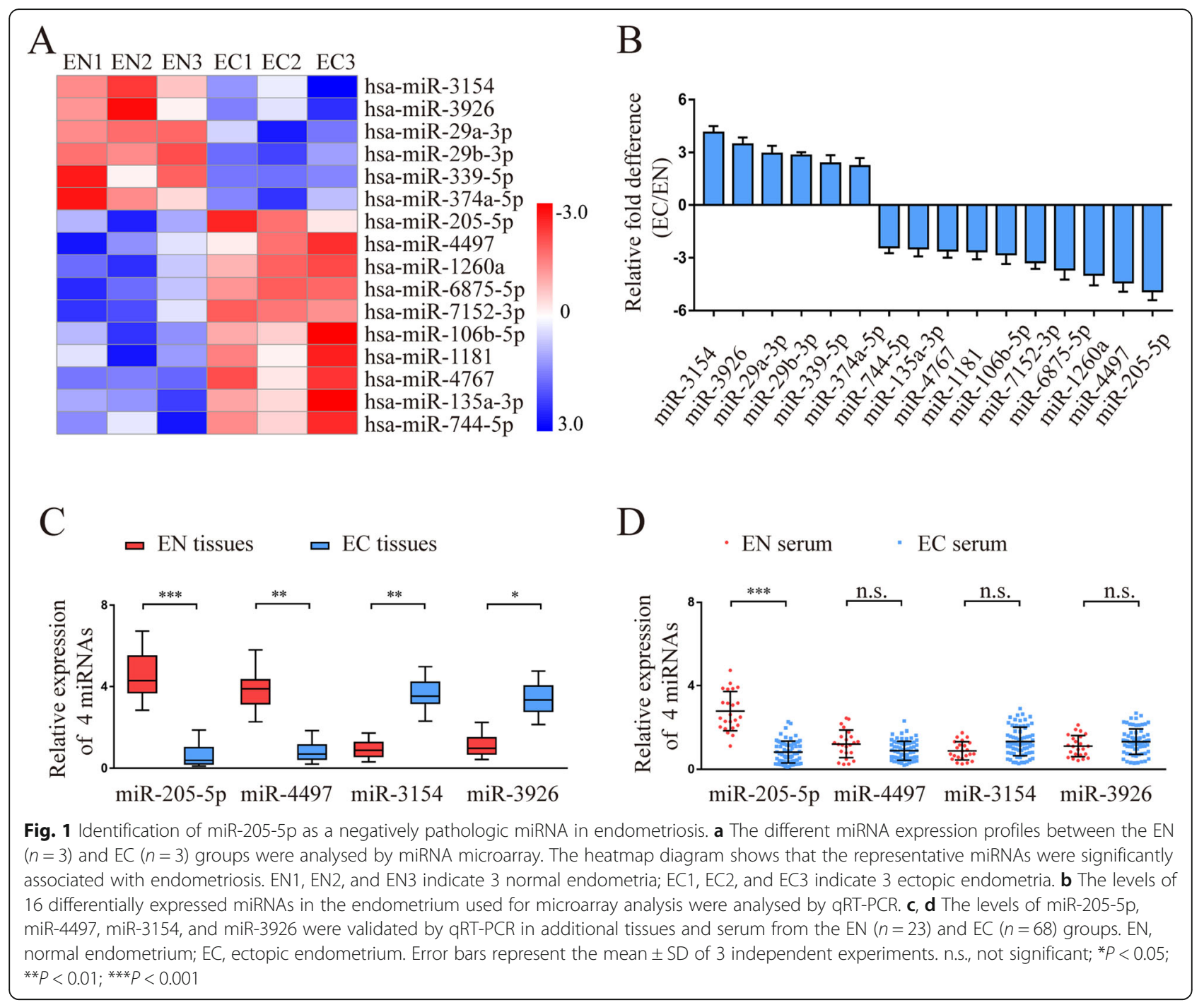

